\title{
Foreign Direct Investments and Economic Growth: The Primary Drivers
}

\author{
Peter Nderitu GITHAIGA \\ School of Business and Economics, Department of Accounting and Finance \\ Moi University, Eldoret, Kenya \\ Tel: 254-722-350-383_E-mail: nderitugithaiga@mu.ac.ke
}

\begin{abstract}
Josiah Nyauncho
School of Business and Economics, Department of Accounting and Finance

Moi University, Eldoret, Kenya
\end{abstract}

Charles Githinji KABIRU

Finance Department, Moi University, Eldoret, Kenya

Received: August 21, 2015 Accepted: Sep. 23, $2015 \quad$ Published: December 1, 2015

doi:10.5296/ajfa.v7i2.8185 URL: http://dx.doi.org/10.5296/ajfa.v7i2.8185

\begin{abstract}
In order to achieve the Global Millennium Development Goals (MDGs) there is need for enhanced global partnerships in areas such as trade, health, security, environmental sustainability, food security and education. Owing to these initiatives Foreign Direct Investments (FDIs), Official Foreign Development Assistance (ODAs) and other external capital flows are increasingly considered as drivers of economic growth for developing countries. By year 2000 FDIs flow to developing countries accounted for $19 \%$ of the total global FDI flow compared to $52 \%$ in 2010 . Collectively FDI equates to $11 \%$ of global GDP and generates close to 80 million jobs globally. Global FDI totaled to US\$ 1.2 trillion in 2010, US\$ 1.4 trillion in 2011 and US\$ 1.8 trillion in 2012. Similarly, the developing countries received half of the FDI and only invested a quarter of the FDI out flow. Studies show that FDIs contributes to economic growth by stimulating several macro-economic and demographic variables which are major agents of economic growth. This paper sought to explain the effect of FDI on the determinants of economic growth human capital
\end{abstract}




\section{Macrothink}

development, financial sector development and trade openness. A sample of 30 African countries was used for the study. The data used was retrieved from UNCTAD and World Bank online databases for the period between 1980 and 2012 and analyzed through a fixed effect regression model. The results of the study show that FDI had a positive impact on measures of financial sector development and trade openness. However the effect of FDI on human capital development was negative. The study recommends the need for favorable monetary policies that elicit more FDI for enhanced economic growth. The study also suggests increased global trade liberalization and integration to boost trade. Finally the study recommends that additional FDI flows should be directed towards human capital development.

Keywords: FDI, Economic Growth, Human Capital Development, Financial Sector Development, Trade Openness

JEL Classification: F23, F36, F43, O40 


\section{Introduction}

The global urge to achieve the Millennium Development Goals (MDGs) by 2015 has led to enhanced and integrated transnational partnerships in trade, health, education and security. These partnerships are demonstrated by the increased flow of FDIs, Official Development Assistance (ODAs) and other foreign capital flows to developing countries. This is true for Africa which in the last five decades received a smaller portion of FDI inflows compared to developed countries (Asiedu, 2003). Today there is unprecedented increase in the volume of FDIs flowing to Africa. For instance in year 2000 FDIs received by developing countries was estimated at $19 \%$ of total global FDIs compared to $52 \%$ in 2010 . FDIs accounts for $11 \%$ of global GDP and creates close to 80 million jobs globally (UNCTAD 2010). Global FDI totaled to US\$ 1.2 trillion in 2010, US\$ 1.42011 and US\$ 1.8 in 2012 notably the developing countries received half of the FDI and invested only a quarter of the FDI out flow (UNCTAD 2012).It should also be noted that foreign direct investment have potentially desirable elements that affect the quality of growth which in the long run effect on poverty reduction, diffusion of technology, capital and managerial transfer and human capital accumulation. FDIs also absorb adverse shocks emanating from inefficiencies in the financial systems that adversely affect the poor population. Besides FDIs support corporate governance through the creation of sound institutional frameworks. Studies show that revenue generated from FDI support the development of safety nets for the underprivileged (Klein, Aaron and Hadji Michael, 2001). Owing to the importance of FDI on economic growth, studies are focusing on the determinants of FDI in developing countries identify supportive infrastructures, technical and managerial skills, macroeconomic stability and sound institutions as the key pull factors of FDI. With globalization interconnectivity ICT has been documented in empirical work (Addison and Heshmati, 2003). Other determinants include lower borrowing costs, economic reforms, and commitments to macro-economic discipline Dabla-Norris et al (2010). FDI and other foreign capital flows such as remittances remain significant external sources of finance for developing countries are face serious credit constraints. Another branch of studies concentrate on the impact of FDIs on the recipient countries economic growth (Alfaro and Chanda 2006,) and technological advancement through a spillover effect associated with transnational interaction. Important to note today is a growing relationship between China and African countries in areas such as trade and infrastructural development as noted by Judith (2006).

\section{Theory and Hypothesis Development}

The impact of FDIs and other foreign capital flows on human capital development, technology transfer and economic growth (through the spillover effect) is extensively debated in literature. Theories in economics claim that an efficient financial sector, political stability and human capital development are the key drivers of a sound and sustainable economic growth. The effect of FDIs on economic growth can be analyzed as either direct or indirect. The direct effect is exhibited by infrastructural development, new businesses, job creation and portfolio investments. Indirectly, FDI leads to improved technical knowhow, transfer of managerial practices and concepts and technology spillovers. FDIs also contributes to capital accumulation through initiating domestic demand and consumption of goods and services 
(Feenstra and Markusen, 1994). Studies by De Mello (1997 and 1999) show that FDIs contributes to new job opportunities, enhancement of technology transfer, and boosts overall economic growth in recipient countries. FDI are classified FDIs as either horizontal or vertical Beugelsdijk et al. (2008). The two types of FDIs have different impacts and these differences arise from the type of FDI and the characteristics of the receiving countries. These country characteristics include economic, political institutions and other factors which determine a country's affinity for FDIs. For instance, developed countries enjoy solid institutional framework which make horizontal FDIs have a higher impact on economic growth than vertical FDIs. Vertical FDIs stimulate demand for labour. There is vast literature on the FDI - human capital - economic growth triangle. The impact of FDI solely depends on a country's capacity to absorb the embodied technologies. This absorptive capacity depends on the level of human capital development. They estimate that 0.45 years of secondary school education is necessary to benefit from an infusion of foreign technology.

The impact of FDIs on human capital development is explained by Lucas and Romer endogenous growth model. Endogenous Growth Model argue that endogenously accumulated human capital has a direct impact on productivity of labour since human capital development is specific to individuals thereby leaving innovation as a stock of knowledge as an exogenous factor. Human capital development is vital for long term growth owing to its direct input into scientific knowledge (Romer, 1990; Aghion and Howitt, 1992) or due to its positive externalities. Lucas (1988) notes that growth differentials among countries originate from transnational variations in human capital development. The key constituents of human capital development are education and health care. Foreign Direct Investment is classified based on the motive behind such foreign capital flows; natural resources FDIs (access to natural resources), market seeking FDIs (increase market share), efficiencies seeking FDIs (reduction of production cost) and Strategic Asset Seeking FDIs (technological transfers) USAID (2005).

Notably FDIs and other foreign capital flows remain important sources of capital for developing and emerging economies thereby prompting academicians, development agencies and governments' agencies to carry out numerous studies focusing on the key drivers of FDIs. Most of these studies are aimed at policy issues that create an enabling economic climate for FDIs to flourish and have a greater macro-economic impact. Some studies argue that real GDP, inflation and political stability as the primary determinants of FDI. Other determinants of FDI include; macro-economic conditions of the recipient country Blonigen (2005); push factor in the source country and pull factor in the recipient country (Fernandez-Arias, Eduordo, 1996); GDP and bi-directional causality, Chowdhury and Mavrotas( 2006) whose findings are premised on economic soundness as a precondition for external capital inflows and vice versa; Trade protection, exchange rates, taxes and institutions (Blonigen 2005); financial markets development (Alfaro et al, 2003); skilled labour (Waldkrich 2010); Superior plant and management expertise (Miyamoto 2003); financial sophistication (Adeniyi et al 2012). Several theories have attempted to explain the magnitude and direction of FDIs and other foreign capital transfers. 
Production Cycle Theory (Vernon 1966) maintains that a production cycle has four stages: innovation, growth, maturity and decline. According to the theory, a product was created for developed and high income markets and as the market matures competition and imitation begins the product is standardized and this pushes the product to lower income markets in developing countries. Subsequently, FDI will flow alongside the product life cycle. Another theory is "The Theory of Exchange Rates on Imperfect Capital Markets" by Itagaki (1981) and Cushman (1985). This theory identifies exchange rate uncertainty as the determinant of FDI. Cushman found that an appreciation in real exchange rate spurred FDI made by US\$ while an appreciation in foreign currency reduced American FDI (Denisia 2010). Based on the theory of exchange rates speculative behaviour on exchange rates therefore determines the magnitude and the direction of FDIs. The Internalization Theory by Buckley and Casson, (1976) modified by Hennart (1982) later revised by Casson, (1983) postulate that multinational corporations capitalize on their own internal capabilities accordingly will organize their internal processes in a manner that maximize specific foreign advantages in production and distribution. Multinational Corporation enjoys certain economies through direct foreign investment compared to other entry strategies to foreign markets. Hyme (1976) found that FDI is a firm-level strategy decision rather than a capital-market financial decision. "The Eclectic Paradigm" theory by Dunning (1988) merges both industrial economics and international trade to explain the existence, activities and strategies of MNEs. The Electric Paradigm theory identifies three sources of competitive advantage which prompts the establishment of MNCs; Ownership advantage, geographical advantage and internalization advantage. Lastly is the "Transaction Cost" theory developed by Coase (1937) that suggest that cost discovering relevant to prices and cost of certainty, if high enough in market place, justifies firms' decisions to coordinate economic activities locally and globally. Since many studies have focused on the effect of FDI on economic growth; this study will shift its focus by looking at the effect of FDIs on the key determinants of economic growth. The concept of economic growth is multifaceted and it's the output of the interaction of a number of variables. Some of the determinants of economic growth are; inflation, trade openness, and current account balance Tolo (2011); demography, education, economic openness, institutions and trade policy Bhalla (2012); rule of law and international, openness, human capital (Barro 2003); human capital and foreign direct investment and stock market liquidity (Salahuddin 2010); terms of trade, improvements on the quality of capital, and the presence of distortions; human and physical capital accumulation Chumacero and Fuentes (2003). The impact of FDI on economic growth is dependent on the casual relationship between remittances and the drivers of economic growth. This paper therefore sought to explain the effects of FDIs on the primary drivers of economic growth namely; Human Capital Development (HCD), Trade Openness (TO), and Financial Sector Development (FSD). These drivers are also considered as pull factors of FDIs and other foreign capital flows. For example on human capital development, a report by UNCTAD (1994:218) note MNCs' "demand for highly trained graduates manifests itself in the form of financial support, particularly to business schools and science facilities, the provision of assistance and advice through membership of advisory boards, curriculum review committees, councils and senates" 
The study had three hypotheses as shown below:

$H_{01}$ Foreign Direct Investment has a positive and statistically significant effect on Financial Sector Development

$\mathrm{H}_{02}$ Foreign Direct Investment has a positive and statistically significant effect on Human Capital Development

$\mathrm{H}_{03}$ Foreign Direct Investment has a positive and statistically significant effect on Trade Openness

\subsection{Conceptual framework}

The diagram below illustrates the conceptual framework of the research. In the diagram Foreign Direct Investment is the independent variable while the three primary drivers of economic growth are considered as the dependent variables.

\begin{tabular}{|c|c|}
\hline \multirow{2}{*}{ Foreign Direct Investment (FDI) } & $\begin{array}{l}\text { Drivers of Economic Growth } \\
\text { - Human Capital Development }\left(\mathrm{H}_{1}\right)\end{array}$ \\
\hline & $\begin{array}{l}\text { - } \quad \text { Trade openness }\left(\mathrm{H}_{2}\right) \\
\text { - } \quad \text { Financial sector development }\left(\mathrm{H}_{3}\right)\end{array}$ \\
\hline
\end{tabular}

Independent Variable

Dependent Variable

\begin{tabular}{|cl|}
\hline Control Variables \\
- & Rate of Inflation \\
- & Exchange Rate \\
- & GDP \\
$\bullet$ & Remittances \\
\hline
\end{tabular}

Figure 1. Conceptual framework

\section{Research Methodology}

The study used a sample of 30 countries and their data for the period between 1980 and 2012(see the list of countries in Table 7). The data used was collected and stored by World Bank's (World Development Indicator Database) (2014) and UNCTAD (2014). FDI was measured as a percentage of the recipient country GDP. This will help control for country size and population. Economic and monetary policies were indexed by the rate of inflation and exchange rates. Trade openness with be measured by the volume of exports as a percentage of GDP while the financial sector development was indexed by domestic credit to Private Sector as a percentage of GDP and bank deposit as a percentage of GDP. Human Capital Development (HCD) is measured by health component indexed by infant mortality rate. The study controlled for monetary policies, GDP per capita income (initial state) and other foreign capital flows and local investment. A country's monetary policy attracts or discourages local and foreign investor. The attractiveness of monetary policies is measured 
by exchange rates $(\mathrm{EXCH})$ and the level of inflation (INF). The determinants of economic growth were influenced by government and private citizens' investments. Gross capital formation (local investment denoted by LI) controls for the aggregate improvement in a country's capital stock. Apart from FDI a country benefits from other external capital flows such as remittances and foreign aid which also have an impact on economic growth. The effect of these foreign capital inflows on the determinants of economic growth was controlled for by personal remittance received as a percentage of GDP (REM). The research model is shown below;

$$
\mathrm{DEG}_{\mathrm{i} t}=\beta 0_{\mathrm{i}}+\beta_{1} \mathrm{FDI}_{\mathrm{it}}+\beta_{2} \mathrm{MP}_{\mathrm{it}}+\beta 3 G D P_{\mathrm{it}}+\beta 4 \mathrm{LI}_{\mathrm{it}}+\beta_{5} \mathrm{REM}_{\mathrm{i} t}+\mu_{\mathrm{it}} . \text { Where; }
$$

DEG represents drivers of economic growth (Financial Sector Development, Trade Openness and Human Capital Development). FDI represent Foreign Direct Investments (explanatory variable). MP represents monetary policy, GDP denote Gross Domestic Product, REM represents other foreign capital flows and LI local investment both (government and private investment). $\mu t$ denotes an error term

\section{Empirical analysis}

\subsection{Descriptive Statistics}

Table 1 shows the period averages and summary statistics for the research variables for the period 1980-2012. The mean FDI net inflows were estimated at $3.520 \%$ of the GDP of the receiving countries with a minimum value of -6.897 and maximum value of 35.24 . Table 1 confirms a significant increment in FDI in the last decade up from $1.4 \%$ in 1980 to $3.2 \%$ in 2012. The average domestic credit to private sector was estimated at $36.5 \%$ of GDP. Credit to private sector double between 1980 and 2012 as shown by the average values of $2.6 \%$ in 1980 and $4.8 \%$ in 2012. The mean remittances received in the period were $5.38 \%$ of GDP. There was a slight improvement in these transfers of 0.6 . What is worth noting is the fact that remittances are a larger component of the receiving countries GDP compared to GDP. The analysis further show that the combined effect of remittances and foreign direct investment is approximate $7.6 \%$ of GDP compared to an average local investment of $23.26 \%$ of GDP (approximately one-third of local investments)These figures suggest that foreign capital flows are important external sources of finance if well harnessed. The high exchange rate of $90.71 \%$ and inflation of $28.49 \%$ indicate ineffective monetary policies that discourage investment both local and foreign. The table further shows high infant mortality rate averaged at 45 deaths per 1000 of the population which is deterrence to human capital development. 
Table 1. Summary Statistic of the Research Variable

\begin{tabular}{r|rrrrr} 
Variable & obs & Mean & Std. Dev. & Min & Max \\
\hline FDI & 990 & 2.351571 & 3.520934 & -6.897609 & 35.23495 \\
DEPOSIT & 990 & 27.18864 & 353.0369 & -128.9158 & 11046.93 \\
CREDIT & 990 & 36.57213 & 30.61217 & 1.542268 & 319.4609 \\
HCD & 990 & 45.17061 & 30.49665 & 1.7 & 133.5 \\
EXPORT & 990 & 31.02137 & 16.61088 & 3.279997 & 100.949 \\
\hline GDP & 990 & 5328.565 & 9819.106 & 168.7364 & 67435.95 \\
EXCH & 990 & 90.71891 & 215.3887 & .0000245 & 1401.437 \\
INF & 990 & 28.4905 & 395.1565 & -11.16159 & 12338.66 \\
LI & 990 & 23.26887 & 7.992249 & 3.377636 & 74.82202 \\
REM & 990 & 5.385063 & 11.88878 & .0014116 & 106.4789
\end{tabular}

\subsection{Correlation Analysis}

The correlation matrix represented in table show that FDIs are positively correlated with other foreign capital flows, GDP, trade openness (export), investments and domestic credit to private sector investment. The positive link between FDIs and other foreign transfers could be due to similarities of push and pull factors. FDIs and local investments have a dual causality. The existing state of infrastructure attract foreign investors or still foreign investors and donors would be willing to invest on infrastructural development where locals are not willing to invest due to the huge capital outlays, lack of expertise or risks involved. The relationship between FDIs and bank credit is likely to be duo. Availability of credit locally attracts foreign investors; likewise foreign investor interested in lending or interesting in securities can help alleviate credit constraints affecting households. The relationship between FDI and exchange rates, inflation and human capital development is negative. Unfavorable monetary regime inhibits foreign investors. Foreign capital flows are on the other hand associated with the Dutch Disease.

Table 2. Pairwise Correlation of the Research Variables

\begin{tabular}{r|rrrrrrrrrr} 
& FDI & DEPOSIT & CREDIT & HCD & EXPORT & GDP & EXCH & INF & LI & REM \\
\hline FDI & 1.0000 & & & & & & & & & \\
JEPOSIT & -0.0229 & 1.0000 & & & & & & & \\
CREDIT & 0.2362 & -0.0088 & 1.0000 & & & & & & & \\
HCD & -0.1335 & 0.0553 & -0.5388 & 1.0000 & & & & & & \\
EXPORT & 0.2837 & -0.0245 & 0.2017 & -0.3182 & 1.0000 & & & & & \\
GDP & 0.1138 & -0.0120 & 0.6043 & -0.5503 & -0.0676 & 1.0000 & & & & \\
EXCH & -0.0862 & -0.0159 & 0.1277 & -0.1281 & 0.0382 & 0.0375 & 1.0000 & & & \\
INF & -0.0281 & 0.9972 & -0.0313 & 0.0687 & -0.0308 & -0.0235 & -0.0226 & 1.0000 & & \\
LI & 0.3083 & -0.0153 & 0.2074 & -0.1691 & 0.1661 & 0.0225 & 0.0291 & -0.0248 & 1.0000 & \\
REM & 0.2304 & -0.0226 & -0.1113 & 0.1599 & 0.0732 & -0.1726 & -0.1145 & -0.0201 & 0.4520 & 1.0000
\end{tabular}


The study predicts that $1 \%$ increase in FDI stimulates $1.4 \%$ growth in domestic credit to private sector and $0.4 \%$ expansion in bank deposits. However it's only the link between FDI and domestic credit to private sector that was found as statistically significant as confirmed by $\mathrm{t}=8.39$ and $\mathrm{p}=0.000$ as shown in table 3 . The regression results for FDI and bank deposits shown in table 5 with $\mathrm{t}=1.47$ and $\mathrm{p}=0.141$ illustrate that the effect of FDI on bank deposits is statistically insignificant. The study further established a significant and negative relationship between FDIs and human capital development (infant mortality rate) as reported by $\mathrm{t}=-5.71$ and $p=0.000$ as shown in table 4 . The beta coefficient suggests that $1 \%$ increase in FDI contributes to $0.87 \%$ deterioration in health care in the receiving country. The relationship between trade openness FDI was statistically significant and positive $(t=3.8, p=0.000)$ illustrated in table 6. One point improvement in FDI is accompanied by 0.35 point improvement in trade openness. It's therefore logical to conclude that foreign capital flows be it official development assistance, portfolio investments or altruistic transfers such as personal remittances will open up a country's economy.

Table 3. Regression of FDI on Domestic Credit to private sector

\begin{tabular}{r|rrrrrr}
\hline \multirow{2}{*}{ CREDIT } & Coef. & Robust \\
& Std. Err. & $\mathrm{t}$ & $\mathrm{P}>|\mathrm{t}|$ & [95\% Conf. & Interval] \\
\hline FDI & 1.37113 & .7512414 & 1.83 & 0.078 & -.1653311 & 2.907591 \\
GDP & .0021414 & .0006562 & 3.26 & 0.003 & .0007993 & .0034835 \\
EXCH & .0191303 & .0353532 & 0.54 & 0.593 & -.0531751 & .0914357 \\
INF & -.0011974 & .0003237 & -3.70 & 0.001 & -.0018594 & $-.00 \odot 5355$ \\
LI & .2572714 & .1251571 & 2.06 & 0.049 & .0012964 & .5132464 \\
REM & .1376739 & .1419627 & 0.97 & 0.340 & -.1526723 & .4280202 \\
Cons & 13.50807 & 6.13415 & 2.20 & 0.036 & .9623242 & 26.05382
\end{tabular}

Table 4. Regression of FDI on Human Capital Development

\begin{tabular}{r|rrrrrr}
\hline & \multicolumn{5}{|c}{ Robust } \\
HCD & Coef. & Std. Err. & $\mathrm{t}$ & $\mathrm{P}>|\mathrm{t}|$ & {$[95 \%$ Conf. } & Interval] \\
\hline FDI & -.8730139 & .3293321 & -2.65 & 0.013 & -1.546574 & -.1994542 \\
GDP & -.000244 & .0001721 & -1.42 & 0.167 & -.000596 & .0001079 \\
EXCH & -.0289548 & .0150678 & -1.92 & 0.065 & -.0597718 & .0018622 \\
INF & .0028719 & .0003142 & 9.14 & 0.000 & .0022292 & .0035145 \\
LI & -.1469277 & .2457637 & -0.60 & 0.555 & -.6495709 & .3557154 \\
REM & -.4430031 & .2837535 & -1.56 & 0.129 & -1.023344 & .137338 \\
Cons & 56.8733 & 6.44161 & 8.83 & 0.000 & 43.69873 & 70.04787
\end{tabular}


Table 5. Regression of FDI on Bank Deposits (Claims to Private Sector\% GDP)

\begin{tabular}{|c|c|c|c|c|c|c|}
\hline \multirow[b]{2}{*}{ DEPOSIT } & \multicolumn{3}{|c|}{ Robust } & \multirow[b]{2}{*}{$P>|t|$} & \multirow[b]{2}{*}{$\begin{array}{l}95 \% \\
\text { Conf. }\end{array}$} & \multirow[b]{2}{*}{ Interval] } \\
\hline & Coef. & Std. Err. & $\mathrm{t}$ & & & \\
\hline FDI & .4115461 & .3733992 & 1.10 & 0.279 & -.3521409 & 1.175233 \\
\hline GDP & - . ๑๑९2186 &.$\odot \odot \odot 2 \odot 34$ & -1.07 & $\odot .292$ & - . .๑๑6346 &.$\odot \odot \odot 1975$ \\
\hline $\mathrm{EXCH}$ & .0084561 & .0171578 & 0.49 & 0.626 & -.0266355 & .0435477 \\
\hline INF & .8914029 & $.0 \odot \odot 979$ & 910.52 & $\odot . \odot \odot \odot$ & $.88940 \odot 6$ & .8934052 \\
\hline LI & .6107197 & .2393492 & 2.55 & $\odot .016$ & .1211955 & $1.10 \odot 244$ \\
\hline REM & .0055936 & .0626753 & $\odot .09$ & 0.929 & -.1225917 & .133779 \\
\hline _cons & -13.01903 & 5.887971 & -2.21 & $\odot .035$ & -25.06128 & -.976776 \\
\hline
\end{tabular}

Table 6: Regression of FDI on Trade openness

\begin{tabular}{|c|c|c|c|c|c|c|}
\hline \multirow[b]{2}{*}{ EXPORT } & \multicolumn{3}{|c|}{ Robust } & \multirow[b]{2}{*}{$P>|t|$} & \multirow[b]{2}{*}{$95 \%$} & \multirow[b]{2}{*}{ Interval] } \\
\hline & Coef. & std. Err. & $\mathrm{t}$ & & & \\
\hline FDI & .3475294 & .2111934 & 1.65 & 0.111 & - . .8444๑96 & .7794684 \\
\hline GDP & . $\odot \odot 1116$ &.$\odot \odot \odot \odot 684$ & 1.63 & $\odot .113$ & 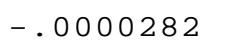 &.$\odot \odot \odot 2514$ \\
\hline $\mathrm{EXCH}$ & .0240264 & .0054303 & 4.42 & $\odot . \odot \odot \odot$ & .0129203 & .0351325 \\
\hline INF & 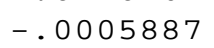 & $.0 \odot \odot 13 \odot 3$ & -4.52 & $\odot . \odot \odot \odot$ & 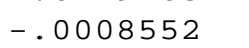 & $-.0 \odot \odot 3223$ \\
\hline LI & -.0291776 & .2098073 & -0.14 & $\odot .890$ & -.4582816 & .3999264 \\
\hline REM & -.1613849 & $.17 \odot 76 \odot 4$ & -0.95 & $\odot .352$ & -.510629 & .1878593 \\
\hline _cons & 28.99464 & 5.422434 & 5.35 & $\odot . \odot \odot \odot$ & 17.90452 & $4 \odot .08476$ \\
\hline
\end{tabular}

\section{Conclusion and Recommendations}

The study concludes that FDIs stimulates financial sector development. FDIs enhance the availability of capital for investment purposes either through direct investments by the foreign investors or indirectly through investment vehicles such us investment banks, money markets or capital markets. The study also established that foreign direct investments boost trade openness. Trade openness could be as a result of market drive FDIs or spillover effect arising from cross border transactions. In the study FDI was found as having undesirable effect on health care replicating Peter and Nunnenkamp (2012) and Wilkinson (2000) who maintain that FDIs contributes to unequal societies that are described by relative deficiency and prolonged stress considered the main channels through which inequality ruins health. This observation is informed by the argument that FDIs are market driven unlike official development assistance and remittances. Many studies show that FDI have a positive effect on economic growth. This study sought to establish the direct impact of FDIs on the primary drivers of economic growth. The study therefore recommends the need for favourable monetary regimes that attracts foreign investments. Favorable monetary regime encompasses stable exchange rates, controlled inflation and interest rate regimes. Favorable monetary policies attract more foreign direct investments for development purposes. The study further recommends preferential trade agreements and market liberation as a way of encouraging international trade. Enhanced international trade facilitates the flow of factors of production including foreign capital. The study further recommends that foreign investors should consider investing directly into human capital development. 


\section{References}

Abdur Chowdhury1, \& George Mavrotas. (2006). FDI and Growth: What Causes What? United Nations Economic Commission for Europe, Geneva, and 2UNU-WIDER, Helsinki

Adeniyi O, Omisakin O, Egwaikhide F, \& Oyinlola A. (2012). Foreign Direct Investment, Economic Growth and Financial Sector Development in Small Open Developing Economies. Economic Analysis \& Policy, 42(1). http://dx.doi.org/10.1016/s0313-5926(12)50008-1

Aghion P., \& Howitt P. (1992). A Model of Growth through Creative Destruction. Econometrica, 60, 323-351. http://dx.doi.org/10.2307/2951599

Alfaro L, Chanda N, Sebrem, \& Sayek. (2003). FDI Spillovers financial Markets and Economic Development. IMF Working Paper WP/03/186

Asiedu, E. (2003). Policy Reform and Foreign Direct Investment to Africa: Absolute Progress but Relative Decline. (Mimeo, Lawrence, KS: Dept. of Economics, University of Kansas).

Balasubramanyam, V. N., M. Salisu, \& D. Sapsford. (1996). Foreign Direct Investment and Growth in EP and IS Countries. Economic Journal, 106, 434, 92-105. http://dx.doi.org/10.2307/2234933

Barro Robert. (2003). Determinants of Economic Growth in a Panel of Countries. Annals of Economics and Finance, 4, 231-274

Beugelsdijk S., Smeets R., Zwinkels R. (2008). The impact of horizontal and vertical FDI on host's country economic growth. International Business Review, 17, 452-472. http://dx.doi.org/10.1016/j.ibusrev.2008.02.004

Blonigen, Bruce. (2005). A Review of the Empirical Literature on FDI Determinants. Atlantic Economic Journal, 33(4), 383-403. http://dx.doi.org/10.1007/s11293-005-2868-9

BRUCE A. BLONIGEN. (2005). A Review of the Empirical Literature on FDI Determinants. Atlantic Economic Journal, 33, 383-403. http://dx.doi.org/10.1007/s11293-005-2868-9

Buckley, P.J., \& Casson, M.C. (1976). The Future of the Multinational Enterprise. Homes \& Meier: London.

De Mello, L. (1997). Foreign Direct Investment in Developing Countries and Growth: A Selective Survey. Journal of Development Studies, 34, 1, 1-34. http://dx.doi.org/10.1080/00220389708422501

De Mello, L. (1999). Foreign Direct Investment Led Growth: Evidence from Time-series and Panel Data. Oxford Economic Papers, 51, 133-51. http://dx.doi.org/10.1093/oep/51.1.133

Dierk Herzer Peter Nunnenkamp. (2012). FDI and Health in Developed Economies: A Panel Co-integration Analysis. Working Paper No. 1756 | February 2012

Dunning, J. H. (1973). The determinants of international production. Oxford Economic Papers 25. 
Dunning, J. H. (1980). Toward an eclectic theory of international production: Some empirical tests. Journal of International Business Studies, 11.

Dunning, J. H. (1988). The Eclectic Paradigm of International Production: A restatement and some possible extensions. Journal of International Business Studies, 19 (Spring).

Era Dabla-Norris, Jiro Honda, Amina Lahreche, \& Geneviève Verdier. (2010). FDI Flows to Low-Income Countries: Global Drivers and Growth Implications IMF working paper $\mathrm{WP} / 10 / 132$

Feenstra R. C., \& Markusen J. R. (1994). Accounting for Growth with New Inputs. International Economic Review, 35.

Fernandez-Arias, Eduordo. (1996). The New Wave of Private Capital Inflows: Push or Pull?" Foreign Direct Investmen. Cambridge, MLT Press. http://dx.doi.org/10.1016/0304-3878(95)00041-0

Hymer, S (1976). (1960 dissertation). The International Operations of Nation Firms: A Study of Journal of Development Economics, 48(2), 389-418.

Judith van de Looy. (2006). Africa and China: A Strategic Partnership? ASC Working Paper /67/ 2006 African Studies

Klein, M., C. Aaron, \& B. Hadjimichael. (2001). Foreign Direct Investment and Poverty Reduction. Paper presented at the OECD Conference on New Horizons and Policy Challenges for Foreign Direct Investment in the 21st Century, 26-27 November (Mexico City). http://dx.doi.org/10.1596/1813-9450-2613

Lucas R. Jr. (1988). On the mechanics of economic development. Journal of Monetary Economics, Elsevier, 22(1), 3-42. http://dx.doi.org/10.1016/0304-3932(88)90168-7

Miyamoto, K. (2003). Human Capital Formation and Foreign Direct Investment in Developing Countries. OECD Development Centre Working Paper No. 211.

Mohammad Salahuddin. (2010). The Determinants of Economic Growth in Pakistan: Does Stock market development play a major role? International Conference on Applied Economics.

Romer P. (1990). Endogenous Technical Change. Journal of Political Economy, 98(5), 71-102. http://dx.doi.org/10.1086/261725

Rómulo A., Chumacero J., \& Rodrigo Fuentes. (2003). On the Determinants of the Chilean Economic Growth Central Bank of Chile. Working Papers No. 134 Enero 2002

Stephen T., \& Chatham H. (2005). Foreign Direct Investment in Africa. The Private Sector Response to Improved Governance. International Economic Programme IEP BP/05/06

Surjit S. Bhalla. (2012). Determinants of economic growth. Peterson Institute of International Economics. 
UNCTAD. (1994). World Investment Report 1994: Transnational Corporations, Employment and the Workplace, United Nations, New York and Geneva.

USAID. (2005). Foreign Direct Investment: Putting it to Work in Developing Countries. Washington DC.

Vernon R. (1966). International investment and international trade in the product cycle. Quarterly Journal of Economics, 80, 190-207. http://dx.doi.org/10.2307/1880689

Vintila Denisia. (2010). Foreign Direct Investment Theories: An Overview of the Main FDI Theories. Academy of Economic Studies, Bucharest, 2(2).

Waldkirch, Andreas. (2010). The structure of multinational activity: evidence from Germany. Applied Economics, 42(24). 3119 - 3133. http://dx.doi.org/10.1080/00036840801964872

Wilkinson, R. G. (2000). Mind the Gap: Hierarchies, Health, and Human Evolution. London (Weidenfeld and Nicolson).

Willa Boots J. Tolo. (2011) .The Determinants of Economic Growth in the Philippines: A New Look. IMF Working Paper Asia and Pacific Department WP/11/288

Table 7. List of Countries whose data was used in the study (1980-2012)

1) Algeria

2) Botswana

3) Cameroon

4) Costa Rica

5) Dominican Rep

6) Egypt

7) Guatemala

8) India

9) Israel

10) Jamaica

11) Kenya

12) Jordan

13) Korea

14) Lesotho

15) Mexico

16) Pakistan

17) Senegal

18) Sudan

19) Swaziland

20) Thailand

21) Tunisia 
22) Turkey

23) USA

24) Honduras

25) Australia

26) Bolivia

27) Bangladesh

28) Iceland

29) Fiji

30) Ghana 